\title{
Improving the Activeness and Geography Learning Achievement Through the Application of Problem- Based Learning of the Student of SMAN 1 Kalibawang Kabupaten Kulon Progo.
}

\author{
Apihariswati, Mukminan \\ \{\} \\ S2 Pendidikan Geografi, Universitas Negeri Yogyakarta, Yogyakarta, Indonesia ${ }^{1,2}$
}

\begin{abstract}
Invalid source specified.This research aimed at knowing how much improvement of the activeness and learning achievement of class XA of SMAN 1 Kalibawang through the integration of scientific approach and Problem Based Learning. The research is a classroom action research. The subject of this research was 24 students of class XA of SMAN 1 Kalibawang. This research focus on the improvement the students'activeneswsw and planning and learning achievement. The research design uses 3 steps: planning, implementation of action and observation, and reflection. Data collection techniques chekklist observation. Data analysis techniques used are: quantitative deskriptive. The results showed that the implementation of Problem-Based Learning in learning can improve the activity and learning outcomes of students from the stages of each cycle. This can be seen from the following indicators of success: student learning activity showed an increase of $41.25 \%$, from $43.75 \%$ in pre action, to $65.21 \%$ in cycle 1 , to $74.58 \%$ in cycle 2 and to $85 \%$ in cycle 3 ; the test results showed an increase in the number of students whose value fulfilled the Minimum Learning Completeness (KBM), from only 3 students in the pre-action, to 11 students in cycle 1 , to 19 students in cycle 2, to 22 students in cycle 3. The use of the Problem Based Learning improved the student' activenees and their learning achievement.
\end{abstract}

Keywords: Problem-Based Learning, activeness, learning achievement.

\section{Introduction}

Law No. 20 Year 2003 on National Education System (UUSPN) states that: "education is a conscious effort to create an atmosphere of learning and learning process so that learners actively develop their potential to have spiritual strength, self-control, personality, intelligence, noble character, and skills needed itself, society, nation, and state ". Still in Law no. 20 Year 2003 (Chapter II, article 3) states that: "National Education serves to develop the ability and form the character and civilization of a dignified nation in order to educate the life of the nation, aims for the development of potential learners to become human beings who believe and piety to God Who Glorious, noble, healthy, knowledgeable, capable, creative, independent and become a democratic and responsible citizen ".

Learning activities are an integral part of all the activities of students in studying in educational institutions. According to [1] "learning is a complex act and behavior as the action, 
the learning is only experienced by the students themselves, the students are the determinants of the occurrence or not of the learning process".

The conventional method of geography learning barns is complemented by other learning methods, so it does not just rely on oral information (lectures). The low participation of students can be caused by the lack of proper teachers in determining the use of learning methods. The monotonous and teacher-centered lecture method is less supportive of student learning activities. And to understand geography, students must be active so that they can understand the concepts and theories and apply according to the learning environment and experience of the students.

Referring to Government Regulation Number 19 Year 2005 on National Education Standards (SNP), one of the National Standards of Education is the assessment standard. Furthermore, in the Regulation of the Minister of National Education No. 20 Year 2007 stated that one of the principles of assessment in Education Unit Level Curriculum (KTSP) is a reference to the criteria of Minimal Learning Completeness (KBM). Every school is required to make KTSP which contains KBM.

At the beginning of each school year all teachers are required to enroll KBM according to their own schooling abilities. For the academic year 2016/2017 KBM geography subjects at SMAN 1 Kalibawang is 75 . Meaning that all learners the learning outcome or its value must reach 75 .

Existing data indicate that process and learning result of geography at SMAN 1 Kalibawang not yet optimal. The learning process is still centered on the teacher, the students are less mastering the concept of learning, and less active, not man ask questions and confusion in response to questions or instructions if not guided by the teacher.

One way to involve students is always active in the learning process is to apply learning strategies that are appropriate to the classroom conditions. Barns classes are treated according to the characteristics of the students and their conformity with the learning materials. Application of learning strategies that are more helpful to students in the classroom and provide changes to the activities undertaken by students during classroom learning is one way to increase the liveliness and cognitive power of students.

With Problem Based Learning students are expected to be more active in following learning and more quickly achieve KBM.

\subsection{Diagnosis of class problems}

1. The low learning outcomes of students on geography subjects.

2. The low motivation of students to achieve.

3. The low participation of students in learning geography.

4. Teachers have not adopted a scientific approach with recommended methods.

5. Innovation of teachers in the implementation of geographic learning models involving students actively not fully submitted.

6. Students have not had any useful experiences for student life either in school or outside.

7. Students consider the lesson of geography unimportant.

8. Students look bored in following geography lessons.

\subsection{Focus and Problem Formulation}

In relation to the extent of problems arising in geography learning, this research is focused on:

1. The low learning outcomes of students on geography subjects. 
2. The low activity of students in learning geography.

From the focus of this study can be formulated problem as follows "How to improve the activity and learning outcomes of students on geography subjects through learning Problem Based Learning class XA SMAN 1 Kalibawang".

\subsection{Research Purposes}

To find out how much increase student activity in learning and cognitive abilities of students on geography of student of XA sman 1 Kalibawang through Problem Based Learning.

\subsection{Benefits of research}

By doing this classroom action research is expected to have benefits:

1. Students can understand the geography material, improve their learning activity, and improve learning outcomes

2. For teachers: teachers can better master Problem Based Learning, improve student learning activity, improve learning outcomes side.

\section{Literature Review}

\subsection{Activeness}

In the learning process, students perform various activities with the goal of learning outcomes can be achieved optimally. According to [2] students' activity in learning can be classified as follows: Visual activities, Oral activities, Listening activities, Writing activities, Drawing activities, Motor activities, Mental activities, Emotional activities.

Activity of students in following the learning process is very influential on learning outcomes. According to [3] student activeness can be seen in terms of:

1. Participate in carrying out their learning tasks;

2. Engage in problem solving;

3. Ask other students or teachers if they do not understand the issues they face;

4. Trying to find the various information needed for problem solving;

5. Conduct group discussions in accordance with the teacher's instructions;

6. Assessing her own abilities and the results she gets;

7. Train yourself in solving similar problems or problems;

8. Opportunity to use or apply what is obtained in completing the task or problem it faces.

\subsection{Learning outcomes}

According [1] learning outcomes are the result of an interaction of learning acts. From the teacher side of the teaching act ends with the evaluation process of learning outcomes. From the student side, learning outcomes are the end of the breaking and the peak of the learning process.

Argues theoretically the purpose of education or learning outcomes is divided into three domains (domains), namely: cognitive domain, affective domain, and psychomotor domain [4]. 
Taxonomy is the grouping of goals by domain and learning area. According to [4] there are three domains of learning:

\section{Cognitive domain}

Contains behaviors that emphasize the intellectual aspect, such as knowledge, understanding, and thinking skills. Here are the six aspects or levels of the cognitive domain: knowledge, comprehension, application, analysis, synthesis, evaluation.

\section{Affective domain}

Contains behaviors that emphasize aspects of feelings and emotions, such as interests, attitudes, appreciations, and modes of adaptation. Affective spheres are further divided into five levels: receiving, responding, valuing, organization, characterization by a Value or Value Complex,

\section{Psychomotor Domain}

Contains behaviors that emphasize aspects of motor skills such as handwriting, typing, swimming, and machine operation. Psychomotor domains are classified as follows: perception (perception), readiness (set), guided response, mechanism (mechanism), complex overt response (response), adaptation.

\subsection{Learning With Problem Based Learning}

Formulation of Problem Based Learning (PBL), one of which is quite representative stated by Barrows (1996: 3) that: Problem Based Learning (PBL) is a curriculum and learning process. In its curriculum, it is designed to address issues that require students to gain important knowledge, make them adept at solving problems, and have their own learning strategies and have the skills to participate in teams. The learning process uses a systemic approach to solve problems or face the challenges that will be needed in the career and daily life.

States the characteristics covered in the PBL process as follows [5]:

1. Problems are used as the beginning of learning.

2. Usually the problem used is a real-world problem that is presented in an ill-structured way.

3. Problems usually require multiple perspectives. The solution requires students to use and get the concept of some chapters of subject matter or cross-science to other fields.

4. Problems make students challenged to gain learning in the new learning sphere.

5. Very priority self study (self directed learning).

6. Utilizing a variety of knowledge resources, not from a single source. The search, evaluation and use of this knowledge became an important key.

7. Collaborative, communicative and cooperative learning. Students work in groups, interact, teach each other, and make presentations.

The PBL process will work if the teacher slaps with all the necessary tools. Students must also understand the process, and have formed small groups. Then each small group runs a 7 step process in the PBL. According to [6] there are 7 (seven) steps in the PBL as follows: (1) clarify the terms and concepts that are not yet clear; (2) formulate the problem; (3) analyze the problem; (4) organize ideas and systematically analyze them with deep; (5) formulating learning objectives; (6) seeking additional information from other sources (outside of group discussions); (7) synthesize (combine) and test new information, and create reports for teachers / classes. 


\subsection{Classroom Action Research}

Kemmis and Mc. Taggart (1988) writes that in the world of action research education is used in the development of school-based curriculum, professional development of education, school improvement programs, and planning and policy systems.

Kemmis and Mc Taggart identified 17 key items that characterize the study of educational action claims, some of which are as follows:

1. Action research is an approach to improve the implementation of a program by making a change (intervention) and learning from experience in the changes made.

2. Action research is participatory research, i.e. research involving program implementers working towards improving their workings.

3. Action research is carried out through a sell-reflecive spiral, a recurring spiral cycle that includes: planning, acting, systematic observation, reflecting and re-planning, so on, as can be seen in Figure 2.1 .

4. Action research is collaborative.

5. Action research fosters participants and collaborators into self-critical communities of selfcritical communities through their experience at all stages of action research.

6. Action research is a systematic learning process, in which participants act carefully.

There are three main tasks in making action research designs, namely: a) action plan; b) implementation of action and observation (observation); c) reflection on the actions and implications for the improvement of the program activities studied.

\section{Research Methods}

\subsection{Design of Action Research}

The type of this research is Classroom Action Research which is research done in class with aim to improve the quality of classroom learning practice.

The design used in this research is a design developed by Kemmis and Mc Taggart. According to Kemmis and Mc Taggart [7], each cycle of classroom action research involves four stages: planning, action, observation, reflection.

The results of the discussions conducted can be used as a consideration to carry out the next learning activities. Reflection activities consist of evaluation of observations and formulate action plans that can be done to correct the shortcomings of each action implementation.

\subsection{Time and Location of Study}

Time of study in April May 2017 and place of research at SMAN 1 Kalibawang Kulon Progo Regency.

\subsection{Subjects and Characteristics}

Subjects in this study were students of class XA SMAN I Kalibawang. The choice of this class because the learning and learning activities of geography in the class is not optimal so that later it is expected will increased. 


\subsection{Action Scenario}

The type of action in this research is the study of Geography at SMAN 1 Kalibawang using Problem Base Learning to improve the learning result of geography. This technique allows students to be more actively involved in the learning process, so that learning activities become interesting and the results of learning geography on the students will increase. Action done in this research is study of geography by applying Model Problem Base Learning. The expected result is a continuous increase in test result scores from the first cycle to the next cycle according to the existing research design.

\subsection{Data Collection Techniques and Instruments}

Methods of data collection in this study were conducted through: observation, documentation, test.

The instruments used in this study are observation guides, field notes, and documentation of activities such as: observation sheets, tests, field notes.

\subsection{Criteria for Action Success}

The indicators of success in this study are:

1. Increased understanding of students' concepts is $75 \%$ of all students in class are able to meet the Minimum Exhaustiveness Criteria (KKM) is 75. This is seen from the post test cycles 1,2 , and 3 .

2. Increased learning activeness. This is seen from the observation of activity from cycle to next cycle.

\subsection{Data analysis technique}

Data analysis techniques in this study are: data reduction (data reduction), presentation of data (data display), conclusion drawing (conclusion drawing).

\section{Research Result And Discussion}

\subsection{Description Initial Conditions}

Activeness at initial conditions is observed in the lesson before action is taken. Observations were made on aspects of discussion, cooperation and activeness in previous learning that is on weather and climate material. Observation of student learning activeness is done by using observation sheet with score 1 to 5 . Score $5=$ very good, score $4=$ good, score $3=$ enough, score 2 = less, score 1 = very less.

Table 1. Activity Observation Results of Student Pre Action.

\begin{tabular}{cccc}
\hline No. & \multicolumn{1}{c}{ Activeness that observed } & Total Score & Persentage (\%) \\
\hline 1. & Participate in carrying out its duties & 56 & 46.67 \\
2. & Involved in problem solving & 53 & 44.17 \\
\hline
\end{tabular}




\begin{tabular}{|c|c|c|c|}
\hline 3. & $\begin{array}{l}\text { Ask other student or teachers if they do } \\
\text { not understand the problems they are } \\
\text { facing }\end{array}$ & 54 & 45 \\
\hline 4. & $\begin{array}{l}\text { Trying to find the various information } \\
\text { needed for troubleshooting }\end{array}$ & 55 & 45.83 \\
\hline 5. & $\begin{array}{l}\text { Carry out group discussions as intructed } \\
\text { by the teacher }\end{array}$ & 48 & 40.00 \\
\hline 6. & Assess his ability and result obtained & 50 & 41.67 \\
\hline 7. & $\begin{array}{l}\text { Train yourself in solving problem or } \\
\text { similar problem }\end{array}$ & 55 & 45.83 \\
\hline 8. & $\begin{array}{l}\text { The opportunity the use apply what is } \\
\text { gained in solving the problem. }\end{array}$ & 49 & 40.83 \\
\hline & Amount & 420 & 350 \\
\hline & Everages & 52.5 & 43.75 \\
\hline \multicolumn{4}{|c|}{ Notes : maximum score is 120} \\
\hline
\end{tabular}

The observation of students' geography learning activity is still low because the average shows in number 52.5 atau $43.75 \%$. The lowest activity is carry out group discussions as instructed by the teacher. Based on observation data of student activeness can be concluded that carry out discussion as instructed by the teacher is still very low. So that action needs to be done that can improve student activeness.

\subsection{Results of Geography Learning}

Learning outcomes at baseline were obtained from pre-action results on weather and climate materials. Students are asked to do essay writing essay as much as 10 questions to know the initial understanding of students. The value obtained in the analysis to determine the learning outcomes in the initial pre-action conditions for subsequent action.

Table 2. Pre-Action LearningResults

\begin{tabular}{clc}
\hline No & \multicolumn{1}{c}{ Aspects } & Value \\
\hline 1 & The lowest value & 20 \\
2 & The highest value & 90 \\
3 & Average value & 58.75 \\
4 & Value range & 70 \\
& Student above KKM & 3 \\
\hline
\end{tabular}

From the table is known that the above KBM atleast $12.5 \%$.

\subsection{Cycles 1, 2, and 3}

This classroom action research was conducted in XA SMAN 1 Kalibawang class in May 2017. Some of the problems in this research are the low activity and the learning result of Geography. This is because teachers have not used the right method to help students learn geography learning materials so that students assume that geography lessons are difficult, boring and uninteresting. The selection of appropriate methods needs to be done to solve the problem. The method in question is Problem Based Learning. 
This classroom action research consists of 4 activities: pre-action, cycle 1, cycle2, cycle 3 . Problem Based Learning method in geography learning can increase student activity and learning outcomes.

The result of observation shows that the use of Problem Based Learning method has an impact on the activity and learning result of geography. Here is the description of the observation result:

\section{Activity Learning}

The observed learning activity of geography from pre-action, cycle 1 , cycle 2 , and cycle 3 shows improvement. The average of geographic learning activity can be seen in the following table:

Table 3. Increase of Average of Students' Involvement in Learning Geography

\begin{tabular}{|c|c|c|c|c|c|c|c|c|c|}
\hline \multirow[t]{2}{*}{ No. } & \multirow[t]{2}{*}{ Observed Aspect } & \multicolumn{2}{|c|}{ Pre-Action } & \multicolumn{2}{|c|}{ Cycle 1} & \multicolumn{2}{|c|}{ Cycle 2} & \multicolumn{2}{|c|}{ Cycle 3} \\
\hline & & Score & $(\%)$ & Score & $(\%)$ & Score & $(\%)$ & Score & $(\%)$ \\
\hline 1. & $\begin{array}{l}\text { Participate in } \\
\text { carrying out their } \\
\text { learning assignments }\end{array}$ & 56 & 46.67 & 83 & 69.17 & 92 & 76.67 & 106 & 88.33 \\
\hline 2. & $\begin{array}{l}\text { Get engaged in } \\
\text { problem solving }\end{array}$ & 53 & 44.17 & 73 & 60.83 & 88 & 73.33 & 97 & 80.83 \\
\hline 3. & $\begin{array}{l}\text { Ask other students or } \\
\text { teachers if they do } \\
\text { not understand the } \\
\text { problem at hand }\end{array}$ & 54 & 45 & 75 & 62.50 & 87 & 72.50 & 98 & 81.67 \\
\hline 4. & $\begin{array}{l}\text { Try to find various } \\
\text { information needed } \\
\text { for problem solving }\end{array}$ & 55 & 45.83 & 78 & 65.00 & 91 & 75.83 & 101 & 84.17 \\
\hline 5. & $\begin{array}{l}\text { Conduct group } \\
\text { discussions in } \\
\text { accordance with } \\
\text { teacher's instructions }\end{array}$ & 48 & 40.00 & 80 & 66.67 & 91 & 75.83 & 104 & 86.67 \\
\hline 6. & $\begin{array}{l}\text { Assessing abilities } \\
\text { and the results he } \\
\text { obtained }\end{array}$ & 50 & 41.67 & 79 & 65.83 & 88 & 73.33 & 105 & 87.50 \\
\hline 7. & $\begin{array}{l}\text { Train themselves in } \\
\text { solving similar } \\
\text { problems or } \\
\text { problems }\end{array}$ & 55 & 45.83 & 81 & 67.50 & 88 & 73.33 & 102 & 85.00 \\
\hline 8. & $\begin{array}{l}\text { Take opportunity to } \\
\text { use and apply what is } \\
\text { obtained in } \\
\text { completing the task } \\
\text { or problem faced }\end{array}$ & 49 & 40.83 & 77 & 64.17 & 91 & 75.83 & 103 & 85.33 \\
\hline & Number & 420 & 350 & 626 & 521.68 & 716 & 596.64 & 816 & 680.00 \\
\hline & Avarage & 52.5 & 43.75 & 78.25 & 65.21 & 89.50 & 74.58 & 102 & 85.00 \\
\hline $\begin{array}{l}\text { Note } \\
\text { is } 12\end{array}$ & the maximum score & & & & & & & & \\
\hline
\end{tabular}

Based on the table 3 above it can be seen that overall, student learning activities have increased from pre-action to cycle 3 . The average value of student learning activities on pre- 
action amounted to $43.75 \%$. The use of Problem Based Learning in cycle 1 increased student activity by $21.46 \%$ to $65.21 \%$. The condition of students who have started to get used and understand the model of Problem Based Learning is supported by teacher guidance, in cycle 2, student learning activity increased by $9.25 \%$ to $74.58 \%$. This research is still below target so that it is continued to cycle 3 . And in cycle 3, it can be increased by $10.42 \%$ to $85 \%$ so that it has reached the target.

\section{Learning Outcomes}

Learning outcomes are the abilities students have after receiving their learning experience. The learning outcomes in this study were obtained by the tests performed at the end of the preaction, the end of cycle 1, the end of cycle 2, and the end of cycle 3 The use of Problem Based Learning model improves student learning outcomes. Improvement of student learning can be seen in the following table:Based on the above graph it is known that there is an increase in the average value of students' learning ranging from pre-action to cycle 3 . Students who received a complete predicate as man y as 22 students increased 19 students from pre-action. This has exceeded the achievement of the target in the study of $75 \%$ of students get a complete predicate (KKM: 75).

\begin{tabular}{ll}
\multicolumn{1}{c}{ LIST OF VALUE CLASS XA SMAN I KALIBAWANG } \\
$\begin{array}{l}\text { Subject } \\
\text { Competency Standards }\end{array}$ \\
$\begin{array}{l}\text { Basic Competence } \\
\text { Analyzing elements of geosphere elements }\end{array}$ \\
\hline
\end{tabular}

\begin{tabular}{|c|c|c|c|c|c|}
\hline No. & NAME & $\begin{array}{c}\text { Pre-action } \\
\text { value }\end{array}$ & Cycle 1 value & Cycle 2 value & Cycle 3 value \\
\hline 1 & Angelica Nanik Mangesti Puri & 40 & 90 & 93 & 80 \\
\hline 2 & Antonio Yunior Ada Leyn & 80 & 70 & 83 & 95 \\
\hline 3 & Butsainah Rifaa' Setyowati & 50 & 50 & 87 & 100 \\
\hline 4 & Cherry Awandita & 30 & 70 & 83 & 90 \\
\hline 5 & David Bramudya Lubis & 50 & 80 & 63 & 70 \\
\hline 6 & Emerentiana Riawati & 90 & 55 & 87 & 80 \\
\hline 7 & Ginanda Mariputri & 60 & 100 & 100 & 100 \\
\hline 8 & Hendra Said & 40 & 80 & 63 & 80 \\
\hline 9 & Husen Fakhrusy Syakirin & 30 & 80 & 50 & 80 \\
\hline 10 & Kritoporus Edhi Perdamaian & 70 & 80 & 83 & 100 \\
\hline 11 & Malik Albayhaqi & 70 & 75 & 87 & 90 \\
\hline 12 & Nabila Salwa Nugraheni & '60 & 90 & 93 & 90 \\
\hline 13 & Nanda Ayu Kartika & 70 & 75 & 97 & 90 \\
\hline 14 & Nian Pratiwi & 70 & 35 & 60 & 100 \\
\hline 15 & Nico Alri Daffa Pratama & 60 & 75 & 75 & 90 \\
\hline 16 & Odilia Intan Pertiwi & 60 & 80 & 100 & 90 \\
\hline 17 & Ranjana Adhitisna Cadha I & 20 & 70 & 100 & 80 \\
\hline 18 & Riska Dwi Lestari & 90 & 90 & 97 & 100 \\
\hline 19 & Sefi Ambarwanti & 60 & 40 & 90 & 100 \\
\hline 20 & Suprihatin & 70 & 65 & 90 & 100 \\
\hline 21 & Wahyu Triadi Nugroho & 60 & 75 & 87 & 80 \\
\hline 22 & Wangisae Rahma Palgunadi & 60 & 55 & 80 & 80 \\
\hline 23 & Yahya Ansori & 60 & 80 & 87 & 70 \\
\hline \multirow[t]{3}{*}{24} & Yolanda Widi Cahyani & 60 & 90 & 93 & 90 \\
\hline & Amount & 1410 & 1750 & 2028 & 2125 \\
\hline & Averages & 58,75 & 72,91667 & 84,5 & 88,54167 \\
\hline
\end{tabular}




\begin{tabular}{lcccc}
\hline $\begin{array}{l}\text { Students with score higher } \\
\text { than KKM }\end{array}$ & 3 & 11 & 19 & 22 \\
$\begin{array}{l}\text { \% Students with score higher } \\
\text { than KKM }\end{array}$ & 12.5 & 45.83333 & 79.16677 & 91.6667 \\
\hline
\end{tabular}

\section{Conclusions}

Based on the results of research and discussion that has been described, it can be concluded several things as follows:

1. Implementation of Problem Based Learning model can increase student activity of class XA SMAN 1 Kalibawang semester 2 academic year 2016/2017. This can be seen from the average activity of discussion and activity during the presentation on pre-action activity, cycle 1 , cycle 2 , and cycle 3 has which significantly improved.

2. Application of Problem Based Learning can improve student learning outcomes of grade XA SMAN I Kalibawang semester 2 know the teachings of 2016/2017. This can be seen from the average value of evaluation on pre-action activities, cycle I, cycle 2 , and cycle 3 has which significantly improved.

\section{Suggestions}

Based on the result of the research, it can be suggested to improve the quality of future geography learning as follows if the teacher wanta to increase the activity and learning outcomes of geography then it is better to use problem based learning.

\section{References}

[1] Dimyati and Mudjiono, Belajar dan Pembelajaran. jakarta: Rineka Cipta., 2013.

[2] A. Sardiman, Interaksi dan Motivasi Belajar Mengajar. Pedonian Bagi Guru dan Calon Guru. Jakarta: CV. Rajawali Pers., 1998.

[3] N. Sujana, Dasar-Dasar Proses Belajar Mengajar. Bandung: Sinar Baru Algedindo., 2004.

[4] B. S. Bloom, Taxonomy of Educational Objectives: The Classification of Educational Goals. Handbook I Cognitive Domain. New York: Longmans, Greet and Co., 1956.

[5] O. S. Tan, Problem Based Learning Innovation.. Using Problem to Power Learning in 21" Century. Singapore: Thomson Learning., 2003.

[6] M. T. Amir, Inovasi Pendidikan Melalui Problem Based Learning. 4th Edition. jakarta: Publisher: Kencana., 2015.

[7] S. Madya., Teori dan Praktik Penelitian Tindakan (Action Research). Bandung: Alfabeta., 2009. 